DOI 10.15290/cnisk.2021.02.11.01

REGINA RENZ

https://orcid.org/0000-0003-1409-4186

Uniwersytet Jana Kochanowskiego w Kielcach

\title{
Małżeństwa w międzywojennej rodzinie chłopskiej w świetle dokumentów kościelnych na przykładzie diecezji kieleckiej
}

\section{Streszczenie}

W środowisku wiejskim najbardziej rozpowszechniony był model rodziny patriarchalnej lansowany przez instytucje religijne. Propagowane na łamach prasy katolickiej ideały związane $z$ modelem rodziny patriarchalnej eksponowały u mężczyzn zaradność, dbałość o żonę i dom, a u kobiet gospodarność, dobroć, troskę o dzieci i męża. Małżeństwa zawierano najczęściej wśród sąsiadów, w ramach sąsiednich wsi, w najbliższej okolicy. W warunkach tradycyjnej gospodarki chłopskiej kryterium podstawowym była powierzchnia gruntów posiadanych przez zainteresowane rodziny oraz kapitał pieniężny. Uczucie miłości, wzajemna atrakcyjność były wartościami w tym modelu pożądanymi, ale niewymaganymi. Za szczęśliwców uważano tych, którym udało się połączyć „godziwy” wybór małżeński z porywem serca. Kojarzenie małżeństw przez swatów, znajomych, członków rodziny odbywało się zawsze w granicach „pola wybieralności”. Model religijnej koncepcji małżeństwa zakładał, że związek małżeński powołany był przede wszystkim w celu prokreacji. Wykluczał on rozwody i traktował zasadę świadomego macierzyństwa jako sprzeczna $z$ moralnością katolicką. W praktyce zachowania katolików różniły się od modelu propagowanego przez Kościół. Kościelno-etyczne zasady głoszace nierozerwalność małżeństwa i zakaz życia „na wiarę” nie były w pełni prze- 
strzegane. $Z$ wypowiedzi duchownych diecezji kieleckiej zamieszczonych w ankiecie dotyczacej moralności rodzinnej parafian z lat 1920-1929 wynika, że zaledwie w kilku parafiach nie stwierdzono samowolnych separacji i życia bez ślubu. Przyczyną separacji były głównie sprawy majątkowe, niezgodność charakterów, bezpłodność, choroba bądź okrucieństwo któregoś z partnerów. Również kościelne zakazy kontroli i planowania urodzin nie były powszechnie akceptowane. Zjawiska te swiadczą o zmianach zachodzacych $\mathrm{w}$ relacjach małżeńsko-rodzinnych w rodzinie chłopskiej w okresie międzywojennym.

Słowa kluczowe: małżeństwo, rodzina chłopska, rodzina patriarchalna, separacje, życie na wiarę, diecezja kielecka

\title{
MARRIAGE IN THE INTER-WAR PEASANT FAMILY IN THE LIGHT OF ECCLESIASTICAL DOCUMENTATION BASED ON THE EXAMPLE OF DIOCESE OF KIELCE
}

\begin{abstract}
The patriarchal family model, promoted by religious institutions, was the most prevalent in the rural areas. Role models, associated with patriarchal family, promoted in the catholic press, exposed features of men, such as resourcefulness, care for his wife and home, meanwhile, for women, these were features such as economy, kindness, care for her children and husband. People looked for future wives and husbands among neighbours, neighbouring villages and in the nearest area. Within traditional rural areas, basic criteria of marriage was the size of the lands owned by the families of the spouses, as well as owned money capital. Love and mutual attraction were desired but not required in this model. Those, who managed to combine "decent" conditions of the future marriage with elation of heart, were considered the lucky ones. Introducing couples by matchmakers, friends or family members had to guarantee "choosable" choices. Religious concept of marriage assumed that procreation is its main objective. It disregarded divorce and considered conscious maternity inconsistent with catholic morality. In practice, Catholics didn't obey behaviour models promoted by the Church. Church's ethical principles about the binding nature of marriage and the ones banning living without entering marriage, weren't fully respected. Based on the survey conducted among priests in diocese of Kielce regarding family morality among congregation in years 192-1929, we learn that in just a few parishes self-willed separations and living without marriage were observed. The main reason behind separations were property issues, irreconcilable differences, infertility, illness or brutality of one of the spouses. Also, ban
\end{abstract}


imposed on birth planning and control wasn't generally respected. All of the above proves changes that were taking place in marriage and family relations in peasant families during inter-war period.

Keywords: marriage, peasant family, patriarchal family, separation, living without marriage, diocese of Kielce

\section{Wstęp}

Z badań socjologiczno-historycznych wynika, że życie rodzin chłopskich upływało $\mathrm{w}$ charakterystycznym dla środowisk wiejskich prowincjonalizmie, a więc tradycyjnym, schematycznym sposobie myślenia, ubierania się, spędzania wolnego czasu, niechętnej na ogól postawie wobec nowości i postępu. Były one pod silnym wpływem instytucji religijnych i związanych $z$ religia tradycji, obrzędów i obyczajów ${ }^{1}$.

W niniejszym artykule zwrócimy jedynie uwagę na strategie i relacje małżeńskie w międzywojennej rodzinie chłopskiej w świetle źródeł kościelnych na przykładzie diecezji kieleckiej. W środowisku wiejskim najbardziej rozpowszechniony był model rodziny patriarchalnej lansowany przez instytucje religijne. Wypracowana przez teologów katolickich doktryna o życiu rodzinnym opierała się głównie na wskazaniach encykliki papieskiej Piusa XI „O małżeństwie chrześcijańskim" (Casti connubii) z 31 grudnia $1930 \mathrm{r}$. Zgodnie ze wskazaniem papieskim hierarchia osób w rodzinie podporządkowywała żonę oraz dzieci mężowi, przyznając jednak żonie jako matce pierwszeństwo w wychowaniu dzieci. Mą̇z i ojciec pełnił funkcję głowy rodziny, żona natomiast, stojąc na straży domowego ogniska, winna była mężowi posłuszeństwo. Zgodnie $z$ tą doktryna do 1934 r. żona przysięgała mężowi posłuszeństwo przed ołtarzem, „by nie sięgać po władzę, jaka została jemu moca boskiego nakazu nadana" ${ }^{2}$.

\footnotetext{
Franciszek Adamski, „Pozycja kobiety w społeczeństwie i jej miejsce w rodzinie”, Zeszyty Naukowe KUL, nr 1, 1971, 45; Danuta Markowska, Rodzina w środowisku wiejskim, (Wrocław-Warszawa: Zakład Narodowy im. Ossolińskich, Wydawnictwo PAN, 1964), 52-54; Stanisław Kawula, Rodzina wiejska. Opieka - kultura-wychowanie, (Warszawa: Zarząd Główny ZSMP, 1982), 25; Janusz Mariański, Religijność w procesie przemian. Szkice socjologiczne, (Warszawa: Instytut Wydawniczy PAX, 1991), 212-213.

2 Michał Strzelecki, „Wizerunek i rola kobiety w katolickiej koncepcji wychowania społecznego w Drugiej Rzeczypospolitej”, w: Krzysztof Jakubiak (red.), Partnerka, matka, opiekun-
} 


\section{Małżeństwa w międzywojennej rodzinie chłopskiej}

Charakterystyczny jest katalog wymogów stawiany dziewczętom, przeznaczony dla szerokich kręgów odbiorców i propagowany w prasie katolickiej. Dziewczęta powinny być ciche, pokorne, skromne, delikatne. Naganne było poprawianie swojej urody i palenie papierosów, a także kokieteria i zalotność. W 1933 r. na łamach „Młodzieży Katolickiej” pisano, że „młode panny nie powinny się malować, fryzować i broń Boże palić papierosów, muszą dbać o swój honor i cześć, nie łowić przyszłego męża kokieterią i zalotnością"

Ksiądz proboszcz z parafii Porąbka w diecezji częstochowskiej przestrzegał:

A przy tym niech każda panna pamięta, że obecnie nie tak łatwo polować na męża za pomoca nagich ramion lub głębokich dekoltów. Nawet nadpsuty młodzieniec, kiedy chce się żenić, to szuka panienki, ale nie wśród tych wydekoltowanych. No nic dziwnego, chce mieć żonę w domu, a nie baletnicę ${ }^{4}$.

Spora wage przywiąywano do wyposażenia materialnego kandydatów na małżonków. Istniał bowiem zwyczaj określający zobowiązania przedmałżeńskie rodziców młodej pary. Zalecano, by „kochająca, praktyczna matka wyekwipowała córkę w dostateczna ilość pościeli i bielizny pościelowej, bieliznę, naczynia stołowe, urządzenia kuchenne, fartuchy, ścierki"5.

Propagowane na łamach prasy katolickiej ideały zwiazane $z$ modelem rodziny patriarchalnej, eksponowały u mężczyzn zaradność, dbałość o żonę i dom, a u kobiet - gospodarność, dobroć, troskę o dzieci i męża ${ }^{6}$. Silnie akcentowano dezaprobatę aspiracji zawodowych kobiet. Podkreślano, że najważniejszym zadaniem kobiety jest małżeństwo i macierzyństwo, a pełnię rozwoju osobowości może kobieta osiagnąć jako dawczyni życia.

Małżeństwo było synonimem rodziny, a akt ślubu wyrażał jednocześnie akceptację rodzicielstwa i gotowość wypełniania jasno

ka. Status kobiety $w$ dziejach nowożytnych od XVI do XX wieku, (Bydgoszcz: Wydawnictwo Uczelniane Wyższej Szkoły Pedagogicznej, 2000), 282-283.

„Dosyć o Janku, teraz o Janinie”, Młodzież Katolicka, nr 10, 1933, 1.

Kronika Parafialna - Parafia Porąbka (diecezja częstochowska), nr 19, 1933, 2.

„Wyprawa”, Rodzina Polska, nr 51, 1929, 159.

„Zalety dobrej gospodyni”, Ojczyzna, nr 3, 1930, 2. 
określonych ról rodzinno-domowych. Uczucie miłości, wzajemna atrakcyjność były wartościami w tym modelu pożądanymi, ale niewymaganymi. Za szczęśliwców uważano tych, którym udało się połączyć „godziwy” wybór z porywem serca?

Badania małżeństw zawartych przed 1945 r. zamieszkałych we wsi wykazały, że dobór rzadko przekraczał granice powiatu $(22 \%)^{8}$. Małżeństwo zawierano przeważnie wśród sąsiadów, w ramach sąsiednich wsi, w najbliższej okolicy. W warunkach tradycyjnej gospodarki chłopskiej kryterium podstawowym była powierzchnia gruntów posiadanych przez zainteresowane rodziny. W międzywojniu kryterium to zostało poszerzone o inne walory materialne, zwłaszcza kapitał pieniężny. Kojarzenie małżeństw, aranżowane lub swobodne, odbywało się zawsze w granicach „pola wybieralności"'.

Rodzice nie zawsze liczyli się z pragnieniami swoich dzieci, układając ich losy według swojej woli i swoich kalkulacji. Kazimierz Mróz w latach 30. pisał o związkach małżeńskich ze swojej rodzinnej wsi Jastrzębia $z$ powiatu radomskiego: „Małżeństwa kojarzą się tu podobnie jak w innych stronach, po wsiach. Przede wszystkim odgrywają rolę morgi, względnie posag, a miłość najczęściej jako dodatek, który przychodzi później ... Młody gospodarz musi szukać żony tam, gdzie może otrzymać odpowiedni posag, który pozwoli mu zaspokoić małżeństwo"10. W podobnym duchu pisał Eugeniusz Morawski z powiatu iłżeckiego:

Kojarzenie małżeństw odbywało się po starodawnemu, na przykład moi rodzice pierwszy raz się widzieli na tak zwanych zaręczynach. Wyswatała ich ciotka. Zdecydowali o ich małżeństwie rodzice. Ojciec mojej matki nie zezwalał wyjść za innych kandydatów, których jak opowiadała miała wielu. Natomiast wola ojca, posłuszeństwo było absolutne. Powiedział „ten będzie twoim

\footnotetext{
7 Danuta Markowska, „Rola kobiety polskiej w rodzinie”, w: Elżbieta Konecka (red.), Kobiety polskie, (Warszawa: Książka i Wiedza, 1986), 204; Regina Renz, Kobieta w społeczeństwie międzywojennej Kielecczyzny. Dom - praca - aktywność społeczna, (Kielce: Wydawnictwo Uniwersytetu Humanistyczno-Przyrodniczego Jana Kochanowskiego, 2008), 74-75.

8 Jadwiga Przychodzeń, „Dobór terytorialny i społeczny małżeństw wiejskich”, Roczniki Socjologii Wsi, t. 2, 1965, 119, 129; Czesław Dyrduł, Stefan Pastuszka, Na wiciowych drogach powiatu stopnickiego 1928-1939, (Kielce: Zakład Poligraficzny, 1992), 23.

9 Barbara Łobodzińska, Młodość, miłość, małżeństwo, (Warszawa: Wiedza Powszechna, 1975), 12-16; Regina Renz, Kobieta w społeczeństwie międzywojennej Kielecczyzny, 81.

10 Kazimierz Mróz, Jastrzębia wieś powiatu radomskiego, (Warszawa: Państwowy Instytut Gospodarstwa Wiejskiego, 1935), 263.
} 
mężem! Tak musi być!”. Zaślubiny ich odbyły się w tym samym karnawale i miesiacu co zaręczyny, to jest 20 lutego 1922 roku. Kolejnym bardzo bliskim mi przykładem, gdzie uczucie miłości i wzajemna atrakcyjność były wartościami drugorzędnymi, chociaż pożądanymi, stało się małżeństwo mojej ciotki, siostry mojego ojca, Zofii Morawskiej z Wojciechem Smagłem. Był on biednym jak mówiono na wsi „posiadał tylko pięć palców u ręki”. Aby móc wziąć za żonę córkę gospodarską wyjechał do Ameryki na zarobek. Tam pracował ciężko przy budowie okrętów. Wrócił po paru latach $z$ zarobionymi dolarami. Kupił 12 morgów ziemi z budynkami w Długowoli. Stał się partnerem i dopiero ożenił się z moją ciotką w 1924 roku $^{11}$.

Taka była sytuacja ówczesnej wsi, w której ziemia stanowiła jedyne bądź główne źródło utrzymania. Toteż rodzice nie chcieli nic uszczuplać z majątku, a dzieci w obawie przed wydziedziczeniem musiały liczyć się $z$ wola rodziców.

Model religijnej koncepcji małżeństwa zakładał, że związek małżeński jest powołany przede wszystkim w celu prokreacji. Jest węzłem dozgonnym obwarowanym nakazem wierności. W 1920 r. na łamach „Kieleckiego Przeglądu Diecezjalnego” pisano:

Popęd płciowy może być użyty tylko do celów rozmnażania i ma się ograniczyć do jednego nierozerwalnego małżeństwa. Wszelkie inne zaspokajanie popędu płciowego, czy to przed małżeństwem lub poza nim, jak również korzystanie $z$ małżeństwa, które wyłącza potomstwo lub mu zapobiega jest grzechem ciężkim ${ }^{12}$.

Jako najbardziej odpowiednią ze względów wychowawczych uważano rodzinę liczna, składająca się z kilkorga dzieci. Według wskazówek zamieszczanych w prasie katolickiej najmniej kłopotów wychowawczych sprawiały dzieci $z$ rodzin wielodzietnych. Pisano, że „błogosławieństwo Boże spływa na dom, w którym jest wiele dzieci, a rodzice którzy darzą licznym potomstwem społeczeństwo, Kościół, państwo jakże sowita nagroda czeka w niebie"13.

\footnotetext{
11 Eugeniusz Morawski, Barwa i zapach mojej ziemi, (Kielce: Kieleckie Towarzystwo Naukowe, 1997), 79.

12 „Zasady moralne w zagadnieniach seksualnych”, Kielecki Przeglad Diecezjalny, nr 25, $1920,4$.

13 „Duszpasterz wobec praktyk neomaltuzjańskich”, Wiadomości Archidiecezjalne Warszawskie, nr 2, 1927, 360.
} 
Brak potomstwa $\mathrm{w}$ opinii społecznej uznawano za brak opieki i błogosławieństwa Bożego. W społeczności katolickiej nie stanowiło to podstawy do unieważnienia związku małżeńskiego. W 1929 roku biskupi polscy w naukach do wiernych podkreślali, że „małżeństwo nie może być unieważnione ani $z$ powodu niewierności, ani z powodu odpadnięcia od wiary katolickiej, lecz rozrywa się przez śmierć jednej strony"14.

Model ten wykluczał rozwody i traktował zasadę świadomego macierzyństwa jako sprzeczna $z$ moralnościa katolicka. Rodził on dramat dzieci nieślubnych. Panna $z$ dzieckiem przynosiła wstyd rodzinie. Często do końca życia dzieci te pozostawały obciążone swym pochodzeniem. Nazywano je bękartami i najduchami ${ }^{15}$. Nieślubne dziecko nie miało prawa do nazwiska ojca ani praw spadkowych po ojcu. Współżycie seksualne poza małżeństwem było najbardziej spektakularnym przestępstwem przeciw moralności rodziny chłopskiej. Największy grzech popełniała mężatka, nieco mniejszy panna, jeszcze mniejszy żonaty mężczyzna, a najmniej kawaler, któremu zarzucało się, że bałamucił, ale tylko wtedy gdy robił to zbyt ostentacyjnie ${ }^{16}$.

Kościół katolicki większe obowiązki wobec małżeństwa nakładał na kobietę niż na mężczyznę. Według znanego teologa i pedagoga, dominikanina Jacka Woronieckiego „przywiązanie do zasad religijnych nie pozwala kobiecie na wchodzenie w zwiazki pozamałżeńskie i cudzołóstwo", bo według niego nawet prawo wyklucza definitywnie taki stan rzeczy, chociażby ze względu na trudności występujące przy ustalaniu ojcostwa. Jego zdaniem kobieta ma obowiązek chronić za wszelka cenę swoje dobre imię, natomiast mężczyzna posiada „większe skłonności do poszukiwania spełnienia poza małżeństwem" ${ }^{\prime 1}$. Żona sobie znanymi sposobami dla dobra rodziny i jego samego powinna zatrzymać męża przy sobie. Powinna uzmysłowić mu, że właśnie ona w pierwszej kolejności jest jego przyjacielem, podpora moralna i duchowa, tylko ona jest jedyną towarzyszką życia i kochanką. Wobec tego istotną rolę odgrywała od-

\footnotetext{
14 „O małżeństwie - biskupi polscy duchowieństwu i wiernym”, Miesięcznik Kościelny dla Archidiecezji Gnieźnieńskiej i Poznańskiej, nr 3, 1929, 28.

15 Wojciech Wiaccek, „Kobieta jako męczennica”, Ojczyzna, nr 50, 1921, 7.

16 Stanisław Siekierski, Etos chłopski w świetle pamiętników, (Kraków: Zakład Wydawniczy „Galicja” Fundacji Artystycznej ZMW, 1992), 84-85.

17 Cyt. za: Katarzyna Kalinowska, „Rola kobiety w myśli społecznej o. Jacka Woronieckiego”, w: Krzysztof Jakubiak (red.), Partnerka, matka, opiekunka, 28.
} 
powiednia prezencja kobiety, sposób bycia, strój. Jacek Woroniecki pod względem wyglądu podzielił płeć żeńską na dwie kategorie: kobiety zaniedbane, które wręcz odpychają swoim niechlujnym ubiorem i wyglądem, oraz takie, które „zbyt przesadnym podkreślaniem urody afiszują się publicznie wzbudzając powszechną zazdrość". Wzorowa mężatka powinna „poprzez odpowiedni strój - schludny, skromny ale niepozbawiony uroku, zwracać uwage męża, zaś otoczenie informować o swoim statusie społecznym"18.

W praktyce zachowania katolików różniły się od modelu propagowanego przez Kościól. Kościelno-etyczne zasady głoszące nierozerwalność małżeństwa i zakaz życia „na wiarę" nie były w pełni przestrzegane. $Z$ wypowiedzi duchownych diecezji kieleckiej, zamieszczonych $\mathrm{w}$ ankiecie dotyczacej moralności rodzinnej parafian z lat 1920-1929 wynika, że zaledwie w kilku parafiach wiejskich nie stwierdzono samowolnych separacji i życia bez ślubu. W tradycyjnych społecznościach wiejskich rozwód, a raczej trwała separacja, były praktycznie i z punktu widzenia ekonomicznego i religijnego nie do pomyślenia, to jednak w szczególnych okolicznościach dochodziło do rozpadu małżeństw i pożycia bez ślubu ${ }^{19}$.

Przyczyną separacji były głównie sprawy majątkowe, emigracja zarobkowa, niezgodność charakterów czy też choroba lub okrucieństwo któregoś z partnerów. Proboszcz z parafii Pierzchnica (dekanat stopnicki) pisał: „Trzy małżeństwa uległy rozbiciu $z$ powodu złego traktowania przez męża awanturnika, który uwag duchowieństwa słuchać nie chce" ${ }^{20}$. W podobnym duchu wypowiadał się ksiądz parafii Czarnca (dekanat włoszczowski). „Jeden z żyjacych w separacji wzią sobie dziewczynę $z$ obcej parafii i z nią żyje. Upomnienia księdza, ani prywatne, ani publiczne $z$ ambony nie skutkuja”"

Oprócz krótkotrwałych separacji były też przypadki trwałego, wieloletniego rozkładu pożycia małżeńskiego. Według relacji księdza z parafii Trzyca (dekanat miechowski): „Cztery stadła małżeńskie rozbite, dwa $z$ powodu ustawicznych kłótni (niedobrane usposobienia), jedno $z$ przyczyn zdrady małżeńskiej, jedno $z$ tej przyczyny, że mąż jakiś nienormalny. Oprócz tego zdarzają się mał-

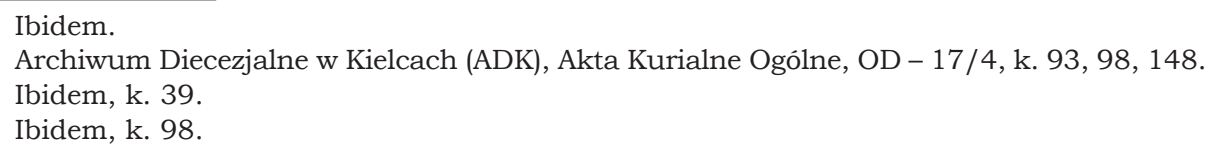


żeństwa chwilowo rozbite $z$ powodu, że jedna ze stron nie spełniła przyrzeczeń, nie przyniosła tyle posagu co obiecano" 22 .

Przyczyną zdrad małżeńskich była również bezpłodność któregoś z małżonków. Ksiądz proboszcz z parafii Chodów (dekanat miechowski) stwierdzał: „Wiaruśnik miał żonę niepłodna, a chciał mieć potomstwo, więc znalazł sobie żonę katoliczkę też zamężną"23.

Zwracano uwagę, że wyjazdy zagraniczne mężów wpływały destrukcyjnie na życie rodzinne. Proboszcz z Wiślicy pisał następujaco o trzech separacjach: „Mężowie od kilku lat w Ameryce. $Z$ początku pisali do swoich żon, teraz nie pisza, choć wiadomo, że żyja”"24. Postulowano nawet, by zwrócić się do władz amerykańskich, aby te zmusiły niewiernych małżonków do przysyłania stałego zasiłku na utrzymanie rodziny. Zdarzało się, że kobiety pozostawione własnemu losowi, często obarczone gromadką dzieci, szukały sobie nowych partnerów i żyły „na wiarę”.

Rodzina chłopska charakteryzowała się zawsze dużą rozrodczością. Przyczyną tego była niewiedza o fizjologii życia seksualnego, niedostatek opieki medycznej oraz wpływ religii nakazującej niekontrolowanie rozrodczości ${ }^{25}$. Według wyliczeń Ludwika Krzywickiego przed pierwszą wojną światową każda kobieta wiejska wydawała na świat w Kongresówce - 5,1 dziecka, w Poznańskiem - 5,7, a w Galicji - 5,9 dziecka ${ }^{26}$. Według wyliczeń Jerzego Zdzisława Holzera współczynnik dzietności w 1931/1932 wynosił dla miast 2,2, a dla wsi 4,1, czyli dla kobiet wiejskich był dwukrotnie wyższy ${ }^{27}$.

Wobec mnożących się rodzinnych działów ziemi i wzrastajacego przeludnienia agrarnego wielodzietność rodzin chłopskich musiała skłaniać ku refleksjom. Co odważniejsi małżonkowie usiłowali ograniczyć liczbe potomstwa. $Z$ przytaczanych już wypowiedzi duchowieństwa diecezji kieleckiej wynika, że w okresie międzywojennym kościelne zakazy kontroli i planowania urodzin nie były powszechnie akceptowane. Księża dosyć często podkreślali, że „co-

\footnotetext{
Ibidem, k. 96.

Ibidem, k. 90.

Ibidem, k. 97.

Stanisław Kawula, Rodzina wiejska, 25.

26 Ludwik Krzywicki, Społeczeństwo pierwotne, jego rozmiary i wzrost, (Poznań: Poznańskie Towarzystwo Przyjaciół Nauk, 2004), 152.

27 Jerzy Zdzisław Holzer, Demografia, (Warszawa: Państwowe Wydawnictwo Ekonomiczne, 1980), 265.
} 
raz więcej dostrzega się unikania potomstwa w formie nieprawidłowych stosunków nie tylko u inteligencji, ale i między ludem"28.

Ksiądz dziekan dekanatu chmielnickiego stwierdzał: „Trudność utrzymania rodziny na wsi wpływa na spadek urodzin. Dążenie do ograniczenia potomstwa u włościan spotyka się nierzadko - szczególnie u rodziców od 36 do 40 lat i więcej, zwłaszcza gdy maja kilkoro dzieci" ${ }^{29}$. Ksiądz proboszcz z parafii Zborówek (dekanat pacanowski) pisał: „Propaganda za unikaniem potomstwa płynie $z$ różnych źródeł. Powracający $z$ robót $z$ Francji, Niemiec tłumaczą kobietom o sposobach (prezerwatywach) unikania potomstwa"30. Proboszcz z parafii Kalina Wielka (dekanat miechowski) zaznaczał, że „akuszerki, lekarze, socjały po miastach ucza sposobów unikania dzieci" ${ }^{31}$. $Z$ kolei proboszcz z parafii Brzegi (dekanat małogoski) dodawał, że „o ograniczeniach urodzin mówi się otwarcie nawet w obecności księdza"32. Przytaczany już proboszcz z parafii Zborówek donosił: „Procuratio abortus nie należy dzisiaj do wypadków bardzo rzadkich. Zabiegu tego dokonuja akuszerki na dziewczynach i kobietach mających mężów poza domem w celu uniknięcia wstydu”33. Ksiądz z Młodzaw (dekanat pińczowski) pisał: „Po wsiach sa akuszerki, które ten proceder (aborcję) uprawiaja, sa to osoby obce, które przywędrowały $z$ miast, a we wsi dobrze im się powodzi"34. Proboszcz z parafii Jańcza (dekanat stopnicki) podkreślał, że „aborcja była najczęściej przez chłopa wymuszona”35.

Duchowni $\mathrm{w}$ sprawozdaniach $z$ wizytacji duszpasterskich zaznaczali, że zmniejszająca się w latach międzywojennych liczebność dzieci nieślubnych była wynikiem aborcji. $Z$ danych dotyczaccych diecezji kieleckiej wynika, że w 1930 r. zarejestrowano tu 29938 dzieci ślubnych i 837 nieślubnych. Przeciętnie na 36 noworodków przypadało 1 dziecko nieślubne ${ }^{36}$. Ksiądz dziekan dekanatu stopnickiego ubolewał: „dzieci nieślubnych w ostatnich prawie pięciu latach prawie nie ma - chyba, że jakaś nędzota w najwyższym

\footnotetext{
28 ADK, Akta Kurialne Ogólne, OD - 17/ 4, k. 29.

29 Ibidem, k. 36.

30 Ibidem, k. 53.

Ibidem, k. 92.

32 Ibidem, k. 182.

33 Ibidem, k. 53.

34 Ibidem, k. 61.

35 Ibidem, k. 31.

36 „Stan religijno-moralny diecezji. Na podstawie sprawozdań duszpasterskich”, Kielecki Przegląd Diecezjalny, z. 6/7, 1931, 184.
} 
stopniu do porodu dopuści" ${ }^{37}$. Ksiądz proboszcz z parafii Cierno (dekanat jędrzejowski) zauważył, że przypadki aborcji utrzymywane były $\mathrm{w}$ największej tajemnicy i trudne do udokumentowania. $Z$ jego rozeznania wynikało, że w ciagu czterech lat (1925-1929) $\mathrm{w}$ jego parafii dwanaście niewiast dokonało aborcji, w tym dziewięć będących w służbie dworskiej ${ }^{38}$.

$Z$ analizy materiałów często tu przytaczanej ankiety dotyczącej moralności rodzinnej wynika, że w okresie międzywojennym wśród rodzin chłopskich wzrastała akceptacja niedozwolonych przez Kościół metod regulacji urodzin, słabło przeświadczenie o obowiazku wstrzemięźliwości przedmałżeńskiej i wierności małżeńskiej. Rozbieżność między moralnością a religia, choć niecałkowita, zaznacza się w sposób widoczny. Chociaż na ogół przypadki te w poszczególnych parafiach nie były liczne, to oddziaływały niekorzystnie na otoczenie. Kościół starał się różnymi sposobami przeciwdziałać negatywnym zjawiskom. W niedzielę Trzech Króli członkowie organizacji katolickich podejmowali próby godzenia zwaśnionych małżonków, a tych, którzy „żyli na wiarę”, nakłaniali, aby rozeszli się lub wstapili w związki małżeńskie ${ }^{39}$.

Duchowni w stosunku do tych osób stosowali represje o charakterze religijnym: opuszczanie podczas kolędy, odmawianie święcenia pokarmów $\mathrm{w}$ czasie wielkanocnym, strofowanie $z$ ambony. Księża zaznaczali, że tylko czasami represje te przynosiły oczekiwane rezultaty, ponieważ rząd pozwala zmieniającym religię wstępować w związki małżeńskie ${ }^{40}$.

\section{Zakończenie}

Przytoczone w niniejszym artykule przykładowe fakty wskazuja, że chociaż omawiane zjawiska nie były powszechne, to odzwierciadlają one tendencje zmian zachodzacych w relacjach małżeńsko-rodzinnych w rodzinie chłopskiej. Należy tu zgodzić się $z$ teza ks. Janusza Mariańskiego, że rozdźwięk między normami kościelno-etycznymi a świeckimi zachowaniami człowieka nie był tylko specyfiką społeczeństw industrialnych ${ }^{41}$.

\footnotetext{
37 ADK, Akta Kurialne Ogólne, OD - 17/4, k. 121.

38 Ibidem, k.182.

39 „Święto rodziny”, Kalendarz Akcji Katolickiej Diecezji Kieleckiej, 1938, s. 32-33.

40 ADK, Akta Kurialne Ogólne, OD - 17/4, k. 35.

41 Janusz Mariański, „Industrializacja a postawy religijne”, w: Franciszek Adamski (red.), Socjologia religii. Wybór tekstów, (Kraków: Wydawnictwo Apostolstwa Modlitwy, 1983), 239.
} 


\section{Bibliografia}

\section{Źródła archiwalne}

Archiwum Diecezjalne w Kielcach.

Akta Kurialne Ogólne, sygn. OD - 17/4.

\section{Prasa}

„Kalendarz Akcji Katolickiej Diecezji Kieleckiej”, 1938.

„Kielecki Przegląd Diecezjalny”, nr 25, 1920.

„Kielecki Przegląd Diecezjalny”, z. 6/7, 1931.

„Kronika Parafialna - Parafia Porąbka” (diecezja częstochowska), nr 19, 1933.

„Miesięcznik Kościelny dla Archidiecezji Gnieźnieńskiej”, nr 3, 1929.

„Ojczyzna”, nr 50, 1921; nr 3, 1930.

„Rodzina Polska”, nr 51, 1929.

„Wiadomości Archidiecezjalne Warszawskie”, nr 2, 1927.

\section{Opracowania}

Adamski, Franciszek. „Pozycja kobiety w społeczeństwie i jej miejsce w rodzinie”, Zeszyty Naukowe KUL, nr 1, 1971, 45-52.

Dyrduł, Czesław. Pastuszka Stefan. Na wiciowych drogach powiatu stopnickiego 1928-1939, (Kielce: Zakład Poligraficzny, 1992).

Holzer, Jerzy Zdzisław. Demografia, (Warszawa: Państwowe Wydawnictwo Ekonomiczne, 1980).

Kalinowska, Katarzyna. „Rola kobiety w myśli społecznej o. Jacka Woronieckiego”, w: Krzysztof Jakubiak (red.), Partnerka, matka, opiekunka. Status kobiety $w$ dziejach nowożytnych od XVI do XX wieku, (Bydgoszcz: Wydawnictwo Uczelniane Wyższej Szkoły Pedagogicznej, 2000), 278-287.

Kawula, Stanisław. Rodzina wiejska. Opieka - kultura-wychowanie, (Warszawa: Zarząd Główny ZSMP, 1982).

Krzywicki, Ludwik. Społeczeństwo pierwotne, jego rozmiary i wzrost, (Poznań: Poznańskie Towarzystwo Przyjaciół Nauk, 2004).

Łobodzińska, Barbara. Młodość, miłość, małżeństwo, (Warszawa: Wiedza Powszechna, 1975).

Mariański, Janusz. „Industrializacja a postawy religijne, w: Franciszek Adamski (red.), Socjologia religii. Wybór tekstów, (Kraków: Wydawnictwo Apostolstwa Modlitwy, 1983), 228-244. 
Mariański, Janusz. Religijność $w$ procesie przemian. Szkice socjologiczne, (Warszawa: Instytut Wydawniczy PAX, 1991).

Markowska, Danuta. Rodzina $w$ środowisku wiejskim, (Wrocław - Warszawa: Zakład Narodowy im. Ossolińskich. Wydawnictwo PAN, 1964).

Markowska, Danuta. „Rola kobiety w polskiej w rodzinie”, w: Elżbieta Konecka (red.), Kobiety polskie, (Warszawa: Ksiażka i Wiedza, 1986), 184-224.

Morawski, Eugeniusz. Barwa i zapach mojej ziemi, (Kielce: Kieleckie Towarzystwo Naukowe, 1997).

Mróz, Kazimierz. Jastrzębia wieś powiatu radomskiego, (Warszawa: Państwowy Instytut Gospodarstwa Wiejskiego), 1935.

Przychodzeń, Jadwiga. „Dobór terytorialny i społeczny małżeństw wiejskich", Roczniki Socjologii Wsi, t. 2, 1965, 115-126.

Renz, Regina. Kobieta w społeczeństwie międzywojennej Kielecczyzny. Dom - praca - aktywność społeczna, (Kielce: Wydawnictwo Uniwersytetu Humanistyczno-Przyrodniczego Jana Kochanowskiego, 2008).

Siekierski, Stanisław. Etos chłopski w świetle pamiętników, (Kraków: Zakład Wydawniczy „Galicja” Fundacji Artystycznej ZMW, 1992).

Strzelecki, Michał. „Wizerunek i rola kobiety w katolickiej koncepcji wychowania społecznego w Drugiej Rzeczypospolitej", w: Krzysztof Jakubiak (red.), Partnerka, matka, opiekunka. Status kobiety $w$ dziejach nowożytnych od XVI do XX wieku, (Bydgoszcz: Wydawnictwo Uczelniane Wyższej Szkoły Pedagogicznej, 2000), 269-277.

Wiącek, Wojciech. „Kobieta jako męczennica”, Ojczyzna, nr 50, 1921, 4-9. 